\title{
ТРИДІАФРАГМОВИЙ ПОЛЯРИЗАТОР
}

А.В. Булашенко ${ }^{1}$, С.І. Пільтяй${ }^{1}$, В.В. Добрийвечір ${ }^{1}$,

О.В. Булашенко ${ }^{2}$, І.В. Забегалов ${ }^{2}$;

${ }^{1}$ Київський політехнічний інститут ім. Ігоря Сікорського

${ }^{2}$ Шосткинський фаховий коледж ім. Івана Кожедуба

a.bulashenko@kpi.ua, s.piltiai@kpi.ua, evning@ukr.net

Сьогодні пристрої поляризаційної оборки сигналів широко використовуються різноманітних сучасних комунікаційних системах. Найбільш простими з конструкторської точки зору є поляризатори, що будуються на основі діафрагм [1-2]. Поляризатори на основі штирів $\epsilon$ більш вузькосмуговими [3-4], а комбіновані поляризатори на основі штирів та діафрагм [5-7] мають гірші характеристики. Дуже часто такі пристрої лише моделюють у відомих програмних засобах HFSS та CST MS [8-10]. Але розробці моделей цих пристроїв на сьогодні не багато [11-12]. Отже, задача розробки нових моделей є актуальною.

На рис. 1а зображений поляризатор на основі квадратного хвилеводу с трьома діафрагмами. Моделлю пристрою $є$ хвилевід всередині якого розміщений три діафрагми.

За допомогою методу еквівалентних схем НВЧ [13] була розроблена еквівалентна схема такого пристрою (рис. 1 б).

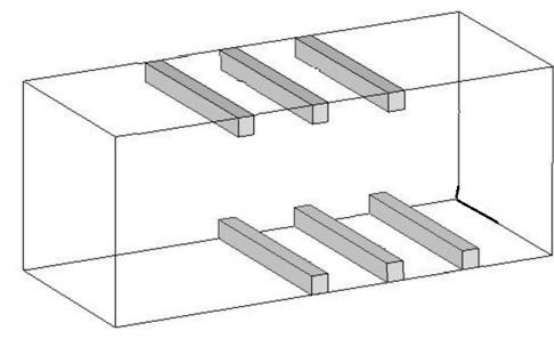

a)

Рис. 1

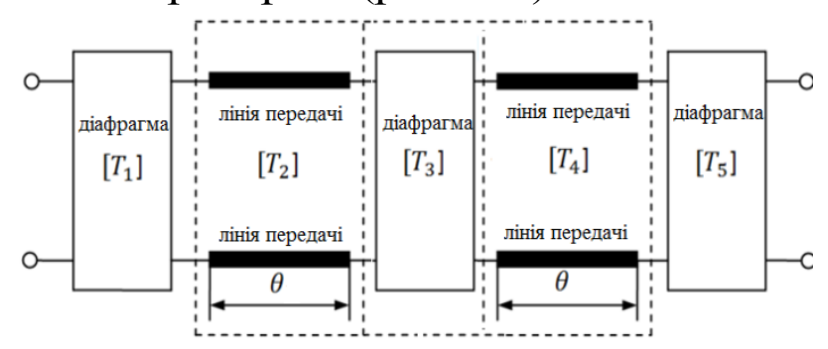

б)

Основні параметри загальної хвильової матриці розсіювання отримуємо на основі методу хвильових матриць [14]

$$
\left[S_{\Sigma}\right]=\left[\begin{array}{ll}
S_{11 . \Sigma} & S_{12 . \Sigma} \\
S_{21 . \Sigma} & S_{22 . \Sigma}
\end{array}\right] .
$$

Основні характеристики пристрою визначимо через ці параметри. Фазовий зсув (рис. 2 а) та коефіцієнт відбиття (рис. 2 б) у робочому діапазоні частот 7.7-8.5 ГГц є основними характеристиками пристрою. Із рис. 2 а демонструє, що пристрій підтримує фазовий зсув $90 \pm 4.8^{\circ}$. Сучасні поляризаційні пристрої [1-2, 8-10, 15] забезпечують такий же зсув. На частоті 8.05 ГГц спостерігається найбільше відхилення фази від $90^{\circ}$, що складає $4.8^{\circ}$. На частотах 7.8 ГГц та 8.36 ГГц зсув фази приймає значення рівно $90^{\circ}$. 


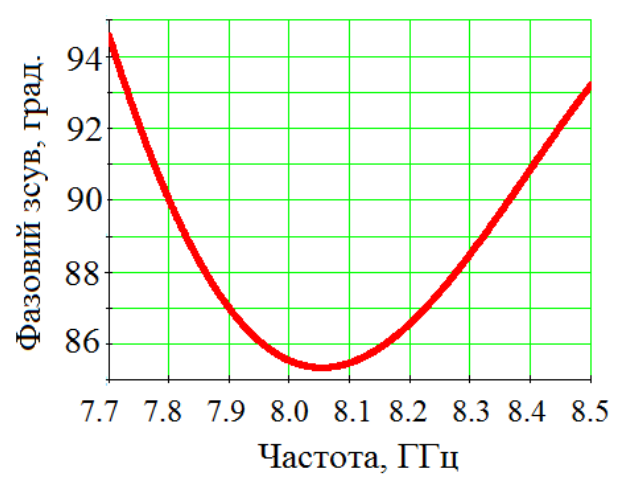

a

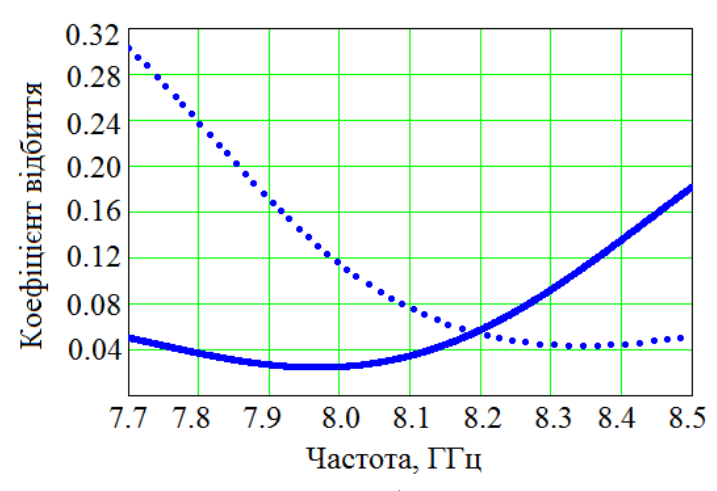

6

Рис. 2

Залежність коефіцієнта відбиття від частоти для поляризатора показана на рис. 2. б. Звідси видно, що для обох поляризації максимальне значення коефіцієнту відбиття становить 0.31. Це свідчить про досить непогане узгодження пристрою.

Отже, було створено модель хвилеводного поляризатора із трьома діафрагмами. Він підтримує фазовий зсув $90 \pm 4.8^{\circ}$ із коефіцієнтом відбиття 0.31 у діапазоні частот 7.7-8.5 ГГц.

Список літературних джерел

1. Piltyay S.I., Bulashenko A.V., Kalinichenko Ye.I., Bulashenko O.V. (2020) High performance waveguide polarizer for satellite information systems, Visnyk Cherkaskogo derzhavnogo tehnologichnogo universitetu, Vol. 4, pp. 14-26. (in Russian). DOI: 10.24025/2306-4412.4.2020.217129.

2. Bulashenko A.V., Piltyay S.I., Demchenko I.V. (2020) Optimization of a polarizer based on a square waveguide with irises. Science-Based Technologies, Vol 47, No 3, pp. 287-297. (in Ukrainian). http://doi.org/10.18372/2310-5461.47.14878.

3. Bulashenko A.V., Piltyay S.I., Kushnir H.S., Bulashenko O.V. (2020) Compact waveguide polarizer with three antiphase posts, Visnyk of Vinnytsia Polytechnical Institute, Vol. 5, pp. 97-104. (in Ukrainian). http://doi.org/10.31649/1997-9266-2020-152-5-97-104.

4. Piltyay S., Bulashenko A., Kushnir H., Bulashenko O. (2020) Information resources economy in satellite systems based on new microwave polarizers with tunable posts, Path of Science, Vol. 6, No 11, pp. 5001-5010. http://doi.org/10.22178/pos.55-1.

5. Bulashenko A.V., Piltyay S.I., Kalinichenko Y.I., Bulashenko O.V. (2020) Tunable square waveguide polarizer with irises and posts. Technical Engineering, Vol. 86, No. 2, pp. 108-116. (in Ukrainian). http://doi.org/10.26642/ten-2020-2(86)-108-116. 